\title{
FIRM SIZE, CURRENT RATIO, DAN RETURN ON ASSET TERHADAP DIVIDEND PAYOUT RATIO
}

\author{
Erlina Widayanti \\ Universitas Pelita Bangsa \\ erlina.widayanti@pelitabangsa.ac.id
}

\begin{abstract}
ABSTRAK
Penelitian ini bertujuan untuk menguji rasio keuangan Firm Size, Current Ratio, dan Return On Asset terhadap Dividend Payout Ratio pada perusahaan jasa sektor Property, Real Estate, dan Konstruksi Bangunan yang terdaftar di BEI. Periode penelitian yang digunakan adalah 3 tahun yaitu 2016-2018. Penelitian ini dilakukan dengan menggunakan data sekunder. Teknik sampel yang digunakan adalah purposive sampling. dari 87 perusahaan Jasa sektor Property, Real Estate, dan Konstruksi Bangunan hanya diambil 29 perusahaan, karena memiliki laporan keuangan secara lengkap. Metode analisis yang digunakan adalah analisis regresi linear berganda. Dengan menggunakan analisa regresi, maka dapat diketahui bahwa Firm Size tidak berpengaruh signifikan terhadap Dividend Payout Ratio, Current Ratio berpengaruh negatif dan signifikan terhadap Dividend Payout Ratio dan Return On Asset tidak berpengaruh signifikan terhadap Dividend Payout Ratio. Dari penelitian yang dilakukan, maka diperoleh kesimpulan bahwa Dividend Payout Ratio dipengaruhi oleh Curent Ratio. Faktor- faktor lain seperti Firm Size dan Return On Asset ternyata tidak berpengaruh terhadap Dividend PayoutRatio.
\end{abstract}

Kata Kunci : Dividend Payout Ratio, Firm Size, Curent Ratio, Return On Asset

\begin{abstract}
This study aims to examine the financial ratios of Firm Size, Current Ratio, and Return On Asset to Dividend Payout Ratio in property, real estate and building construction sector service companies listed on the IDX. The research period used was 3 years, 2016-2018. This research was conducted using secondary data. The sample technique used was purposive sampling. Of the 87 companies in the Property, Real Estate and Building Construction sector services, only 29 were taken because they had complete financial reports. The analytical method used is multiple linear regression analysis. By using regression analysis, it can be seen that Firm Size has no significant effect on Dividend Payout Ratio, Current Ratio has a negative and significant effect on Dividend Payout Ratio and Return On Asset has no significant effect on Dividend Payout Ratio. From the research conducted, it is concluded that the Dividend Payout Ratio is influenced by the Curent Ratio. Other factors, such as Firm Size and Return On Asset, have no effect on the Dividend Payout Ratio.
\end{abstract}

Keywords: Dividend Payout Ratio, Firm Size, Curent Ratio, Return On Asset

\section{PENDAHULUAN}

Pasar modal dikatakan memiliki fungsi keuangan karena memberikan kemungkinan dan kesempatan memperoleh imbal hasil bagi pemilik dana sesuai dengan karakteristik investasi yang dipilih. Dalam aktivitas di pasar modal, para investor memiliki harapan dari investasi yang dilakukannya yang berupa capital gain dan dividen (Khotimah dan Waryati,2015). Dividen merupakan bagian keuntungan yang dibayarkan oleh perusahaan kepada para pemegang saham, oleh karena itu dividen merupakan bagian dari penghasilan yang diharapkan oleh para pemegang saham. Besar kecilnya dividen yang dibayarkan akan mempengaruhi pencapaian tujuan maksimalisasi kesejahteraan pemegang saham (Deitiana,2013).

Kebijakan dividen merupakan suatu pertimbangan yang diambil oleh suatu perusahaan guna membagikan labanya kepada pemegang saham dalam bentuk dividen yang dapat dimanfaatkan untuk pembiayaan operasional dimasa yang akan datang. Kebijakan dividen akan sangat berpengaruh terhadap nilai suatu perusahaan, karena para investor memfokuskan perhatiannya pada kebijakan dividen yang akan diterimanya. Melalui kebijakan dividenlah para investor dapat menentukan 
keputusan investasinya, apakah investasi tersebut layak dibeli, dipertahankan, atau bahkan dijual (Musthofa,2017).

Perusahaan menentukan besar kecilnya dividen yang akan dibayarkan tergantung pada kebijakannya masing-masing, sehingga pertimbangan manajemen sangat diperlukan, salah satu indikator yang menunjukan besarnya nilai dividen yang dibagikan oleh perusahaan kepada investor adalah dividend payout ratio. Semakin tinggi dividend payout ratio akan menguntungkan parainvestor tetapi dari pihak perusahaan akan memperlemah internal financial karena memperkecil laba ditahan. Tetapi sebaliknya dividend payout ratio semakin kecil akan merugikan para pemegang saham tetapi internal financial perusahaan semakin kuat (Nuraeni,2013).

Dividen kas merupakan masalah yang sering menjadi topik pembicaraan diantara para pemegang saham dan juga pihak manjemen perusahaan emiten. Terkadang hal tersebut justru menimbulkan kontroversi antara pemegang saham dan perusahaan (Pradana dan Sanjaya, 2014). Dari berbagai sektor usaha yang ada di Indonesia, sub sektor property, real estate, konstruksi dan bangunan menjadi salah satu sektor usaha yang mengalami fluktuasi yang sangat signifikan dalam pembayaran dividennya yang diukur dengan dividend payout ratio.

Dividend Payout Ratio (DPR) atau rasio pembayaran dividen merupakan faktor yang harus dipertimbangkan, sedangkan jumlah dividen yang dibayarkan tergantung dari kebijakan perusahaan. Jika seluruh laba yang dihasilkan dibayarkan sebagai dividen, perusahaan tidak memiliki cadangan dana untuk melakukan reinvestment, dan sebaliknya jika seluruh laba yang dihasilkan dipertahankan, kepentingan pemegang saham diabaikan, sehingga perusahaan kehilangan kesempatan mendapatkan investor baru (Sunaryo, 2014).

Berbagai macam kendala bisa dihadapi oleh perusahaan sehingga tidak dapat melakukan pembayaran dividen kepada para pemegang saham, hal ini berimbas pada turunnya presentase dividend payout ratio. Sebagai contoh fenomena yang terjadi pada PT. Intiland Development Tbk (DILD), yaitu akibat terjadinya penurunan laba, PT. Intiland Development Tbk (DILD) tidak membagikan dividen ke pemegang saham. Rapat Umum Pemegang Saham (RUPS) PT. Intiland Development Tbk memutuskan untuk tidak membagikan dividen dari laba yang dicapai sepanjang 2018. Dari kinerja perusahaan sepanjang 2018, tercatat laba bersih sebesar Rp 104 miliar atau turun dibandingkan tahun 2017 yang saat itu Rp 271 miliar. Dari sisi pendapatan usaha, Intiland mencatatkan sepanjang 2018 memperoleh Rp 2.202 triliun, sementara tahun 2017 sebesar Rp 2.552 triliun (Merdeka,2018).

PT. Danayasa Arthama Tbk (SCBD) yang tidak membagikan dividen kepada pemegang saham. Dari hasil RUPS bahwa laba tahun berjalan yang didistribusikan kepada pemilik perseroan untuk tahun 2018 sebesar Rp 59,52 miliar dipergunakan untuk dana pengembangan bisnis perseroan, sehingga tidak ada pembagian dividen (Ipotnews, 2019). Hal serupa terjadi pada perusahaan sektor kontruksi dan bangunan yaitu PT. Adhi Karya (Persero) Tbk yang membagikan dividen kepada pemegang saham sebesar 20\% dari laba bersih perusahaan tahun 2018 atau sebesar Rp 128,8 miliar. Tahun lalu, Adhi Karya membukukan kenaikan laba bersih sebesar 24,97\% menjadi Rp 644,15 miliar dibandingkan dengan tahun sebelumnya Rp 515,41 miliar. Laba bersih ini ditopang pendapatan yang tumbuh tipis 3,29\% ke angka Rp 15,65 triliun dari tahun sebelumnya Rp 15,15 triliun (CNBC, 2019).

Kejadian yang dipaparkan pada umumnya terkait dengan kebijakan dividen suatu perusahaan. Begitu pentingnya kebijakan dividen yang diukur dengan dividend payout ratio terhadap banyak pihak, sehingga faktor-faktor yang mempengaruhi kebijakan dividen berdasarkan informasi keuangan yang dipublikasikan oleh perusahaan perlu untuk diidentifikasi. Hal tersebut menjadikan alasan penulis tertarik untuk meneliti tentang kebijakan dividen. Terdapat beberapa faktor yang mempengaruhi perusahaan dalam menjalankan kebijakan dividennya, antara lain Firm Siæe, Current Ratio, dan Return On Asset.

Firm size atau ukuran perusahaan adalah salah satu yang digunakan oleh perusahaan untuk menentukan berapa besar kebijakan struktur modal dalam memenuhi besar asset suatu perusahaan (Ardiana dan Adiyana 2014). dalam hal ukuran perusahaan dilihat dari total asset yang dimiliki oleh perusahaan, yang dapat dipergunakan untuk kegiatan operasi perusahaan. Jika perusahaan memiliki total asset yang besar, pihak manajemen lebih mudah untuk mempergunakan asset yang ada di perusahaan tersebut. Kebebasan yang dimiliki manajemen ini sebanding dengan kekhawatiran yang 
dimiliki oleh pemilik atas asetnya. Jumlah asset yang besar akan menurunkan nilai perusahaan jika dinilai dari sisi pemilik perusahaan. Firm size yang besar juga mampu menggambarkan bila perusahaan memiliki kontrak paling tinggi agar lanjut membetulkan kerjanya, supaya pasar akan siap membiayai lebih tinggi dalam memperoleh sahamnya (Hendry dan Fachrurrozie,2015).

Pertumbuhan suatu perusahaan juga dapat dilihat dari rasio likuiditasnya yaitu Current ratio yang menunjukan sejauh mana kewajiban lancar ditutupi oleh asset yang diharapkan akan dikonversi menjadi kas dalam waktu dekat, investor dapat menggunakan rasio ini untuk mengukurkemampuanperusahaan dalam menutup hutang lancarnya dengan asset (Wahyuni dan Hafiz, 2018).

Faktor lainnya yang mempengaruhi kebijakan dividen adalah Return On Asset yang menunjukan kemampuan perusahaan dalam menghasilkan laba bersih setelah pajak dengan memanfaatkan semua asset yang dimiliki perusahaan. Semakin besar ROA menunjukan kinerja perusahaan yang semakin baik karena tingkat pengembalian investasi atas investasi perusahaan pada aktiva semakin besar. Sehingga pemegang saham dapat memperhatikan besarnya ROA untuk mengukur keuntungan perusahaan yang akan menjadi dasar besarnya dividen yang akan dibayarkan. Ketika ROA perusahaan meningkat, maka memungkinkan perusahaan untuk membayarkan dividen yang lebih besar kepada pemegang saham (Fitri, 2015).

Beberapa penelitian yang berkaitan dengan kebijakan deviden menunjukkan ketidakkonsistenan. (Harun, 2018) dan (Meilina, 2016) menjelaskan bahwa Firm siže tidak berpengaruh terhadap dividend payout ratio. Sedangkan (Yudha, dkk. 2017) dan (Maura, dkk. 2018) menunjukan pengaruh positif signifikan Size terhadap dividen. (Melinda, 2019) menunjukan bahwa faktor current ratio memiliki pengaruh yang positif dan signifikan terhadap dividend payout ratio. Sedangkan hasil penelitian yang dilakukan oleh (Deitiana, 2013), (Yasa dan Wirawati, 2016), dan (Lasmaria, dkk. 2019) menunjukan bahwa tidak ada pengaruh current ratio terhadap dividend payout ratio. (Wahyuni dan Hafiz, 2018) dan (Perpatih, 2016) menunjukan bahwa return on asset memiliki pengaruh yang signifikan terhadap dividend payout ratio. Sedangkan pada penelitian yang dilakukan (Steven, 2017), dan (Welas, 2017) menunjukan bahwa tidak ada pengaruh return on asset terhadap dividend payout ratio.

\section{KAJIAN TEORI}

\section{Kebijakan Dividen}

Kebijakan dividen adalah keputusan apakah laba yang diperoleh perusahaan akan dibagikan kepada pemegang saham sebagai dividen atau akan ditahan dalam bentuk laba ditahan guna pembiayaan investasi dimasa datang. Apabila perusahaan memilih untuk membagikan laba sebagai dividen, maka akan mengurangi laba yang ditahan dan selanjutnya akan mengurangi total sumber dana intern atau internal financing (Lida, 2015). Kebijakan perusahaan membagikan dividen kepada para investor adalah kebijakan yang sangat penting. Kebijakan pembagian dividen tidak saja membagikan keuntungan yang diperoleh perusahaan kepada investor tetapi harus selalu diikuti dengan pertimbangan adanya kesempatan investasi kembali (reinvestment). Apabila dividen dibayarkan secara tunai meningkat, maka semakin sedikit dana yang tersedia untuk reinvestasi. Hal ini menyebabkan tingkat pertumbuhan perusahaan dimasa mendatang menjadi rendah, sehingga akan menekan harga saham (Rodoni dan Ali, 2014).

Pembayaran dividen biasanya dilakukan dalam beberapa tahap dalam satu tahun. Di amerika serikat, pembayaran dividen umumnya dilakukan setiap kuartal. Di Indonesia, praktik pembayaran dividen ada yang satu kali maupun dua kali. Hal lain yang membedakan praktik keputusan dividen adalah berkenaan dengan siapa yang memutuskan besar kecilnya dividen. berbeda dengan Negaranegara maju, misalnya amerika serikat dimana besar kecilnya dividen ditentukan oleh dewan direktur atau manajemen perusahaan, di Indonesia keputusan terhadap seberapa besar dividen akan dibagikan kepada pemegang saham berada dalam Rapat Umum Pemegang Saham (RUPS). Artinya, RUPS memegang peran kunci dalam kebijakan dividen bukan merupakan keputusan strategis dari manajemen perusahaan semata (Gumanti, 2013).

\section{Teori Kebijakan Dividen}

Berikut ini teori-teori kebijakan dividen menurut (Oktaviani dan Basana, 2015) : 
1. Dividend Irrelevance Theory

Miller dan Modigliani (1961) menyatakan bahwa kebijakan dividen perusahaan tidak relevan kepada pemegang saham dan kekayaan saham tidak berubah saat semua aspek kebijakan invetasi tetap. Beberapa asumsi yang mendasari teori ini diantaranya adalah terdapat pasar modal yang sempurna, yaitu tidak ada pajak dan biaya transaksional., manajer bertindak sebagai agen terbaik bagi pemegang saham, dan ada kepastian tentang kebijakan investasi perusahaan.

\section{Bird The Hand Theory}

Menurut Lintner (1956) menyatakan bahwa seorang investor mengharapkan pembayaran dividen yang tinggi, hal ini dikarenakan return pada capital gain tidak pasti atau berisiko. Dividen lebih bisa diramalkan dibandingkan capital gain, manajemen dapat mengontrol dividen, tetapi tidak dapat mengontrol harga saham. Investor kurang yakin akan menerima pendapatan dari capital gain dibandingkan dari dividen. tarif pajak untuk capital gain juga cenderung lebih rendah dibandingkan dividen.

Teori ini menyatakan bahwa nilai perusahaan akan dimaksimalkan dengan menentukan rasio pembagian dividen yang tinggi. Menurut Lintner (1956), ekuitas atau nilai perusahaan akan turun apabila rasio pembayaran dividen dinaikkan, karena para investor kurang yakin terhadap capital gain yang dihasilkan dari laba ditahan dibandingkan seandainya para investor menerima dividen. Lintner (1956), beranggapan bahwa investor memandang satu burung ditangan lebih berharga daripada seribu burung di udara, namun (Miller dan Modigliani) berpendapat bahwa tidak semua investor berkepentingan untuk menginvestasikan kembali dividen mereka di perusahaan yang sama dengan memiliki risiko yang sama, oleh sebab itu tingkat risiko pendapatan mereka di masa yang akan datang bukan ditentukan oleh kebijakan dividen tetapi ditentukan oleh tingkat risiko investasi baru.

\section{Tax Effect Theory}

Suatu teori yang menyatakan bahwa karena adanya pajak terhadap keuntungan dividen dan capital gain, maka para investor lebih menyukai capital gain karena dapat menunda pembayaran dividen (Bringham dan Houston, 2001). Teori ini menyatakan bahwa karena adanya pajak terhadap keuntungan dividen daripada capital gain, para investor lebih menyukai capital gain, karena dapat menunda pembayaran pajak. Investor mensyaratkan suatu tingkat keuntungan yang lebih tinggi pada saham yang memberikan dividend yield tinggi, capital yield rendah dari pada saham dengan dividend yield rendah, capital gain tinggi. Jika pajak dividen lebih besar dari pajak atas capital gain, perbedaan ini akan makin terasa.

\section{Dividend Signalling Theory}

Signal atau isyarat adalah suatu tindakan yang diambil manajemen perusahaan yang memberi petunjuk bagi investor tentang bagaimana manajemen memandang prospek perusahaan (Brigham and Daves, 2013). Peningkatan dividen yang dibayarkan dianggap sebagai signal yang menguntungkan, sehingga menimbulkan reaksi harga saham yang positif. Sebaliknya, penurunan dividen yang dibayarkan dianggap sebagai signal bahwa prospek perusahaan kurang menguntungkan, sehingga menimbulkan reaksi harga saham yang negatif (Brigham and Daves, 2013). Dividend Signalling Theory pertama kali dicetuskan oleh Bhattacharya pada tahun 1979. Teori ini mendasari dugaan bahwa perubahan cash dividend mempunyai kandungan informasi yang mengakibatkan munculnya reaksi harga saham. Teori ini menjelaskan bahwa informasi tentang cash dividend yang dibayarkan dianggap investor sebagai sinyal prospek perusahaan di masa mendatang. Adanya anggapan ini disebabkan terjadinya asymmetric information antara manajer dan investor, sehingga para investor menggunakan kebijakan dividen sebagai sinyal tentang prospek perusahaan. Apabila terjadi peningkatan dividen akan dianggap sebagai sinyal positif yang berarti perusahaan mempunyai prospek yang baik, sehingga menimbulkan reaksi harga saham yang positif. Sebaliknya, jika terjadi 
penurunan dividen akan dianggap sinyal negatif yang berarti perusahaan mempunyai prospek yang tidak begitu baik, sehingga menimbulkan harga saham yang negatif.

\section{Macam-macam Dividen}

Menurut (Sari dan Lestari, 2015) ada beberapa macam dividen yaitu sebagai berikut :

a. Cash Dividend, adalah dividen yang dibayarkan dalam bentuk uang tunai. Pada umumnya cash dividend lebih disukai oleh para pemegang saham dan lebih sering dipakai perseroan jika dibandingkan dengan jenis dividen yang lain.

b. Stock Dividend, adalah dividen yang dibayarkan dalam bentuk saham, bukan dalam bentuk uang tunai. Pembayaran stock dividend juga harus disarankan adanya laba yang tersedia.

c. Property Dividen, adalah dividen yang dibayarkan dalam bentuk barang aktiva selain kas. Aktiva yang dibagikan dapat berbentuk surat-surat berharga perusahaan yang dimiliki, barang dagangan, real estate atau investasi bentuk lain yang dirancang oleh dewan direksi.

d. Script Dividend, adalah dividen yang dibayarkan dalam bentuk surat (script) janji hutang. Perseroan akan membayar sejumlah tertentu dan pada waktu tertentu, sesuai dengan yang tercantum dalam script tersebut.

e. Liquidating Dividen, adalah dividen yang dibagikan berdasarkan pengurangan modal perusahaan, bukan berdasarkan keuntungan yang diperoleh perusahaan.

\section{Prosedur Pembayaran Dividen}

Menurut (Rodoni dan Ali, 2014) Prosedur dalam pembayaran dividen adalah sebagai berikut :

1. Date Of Declaration (tanggal pengumuman),adalah tanggal dimana direksi secara formal mengumumkan pembagian dividen kepada para pemegang saham, suatu utang dividen harus diakui dan laba yang ditahan berkurang. Dengan demikian kewajiban membayar dividen timbul pada saar direksi mengumumkan pembagian dividen.

2. Cum-Dividend Date, adalah tanggal hari terakhir perdagangan saham yang masih melekat hak untuk mendapatkan dividen.

3. Date Of Record (tanggal pencatatan pemegang saham), adalah tanggal dimana kepemilikan saham ditentukan, sehingga dapat diketahui kepada siapa dividen dibagikan. Pemegang saham yang mencatatkan dirinya pada tanggal ini adalah pemegang saham yang memperoleh dividen pada tanggal pembayaran. Tidak ada entry yang diperlukan pada tanggal pencatatan. Tanggal ini hanya digunakan sebagai titik batas, kepada dividen dibagikan. Penentuan titik batas tidak perlu dilakukan karena saham perusahaan diperdagangkan di bursa, sehingga pemiliknya setiap saat dapat berubah. Tentang jumlah saham yang beredar, perusahaan sudah mengetahuinya sejak dividen diumumkan. Pada saat dividen dibayarkan, utang dan kas akan berkurang sehingga perusahaan akan mencatatnya sebagai pengurangan kedua perkiraan tersebut.

4. Ex-Dividend Date (tanggal pemisahan dividen). Sebelum tanggal pencatatan, perusahaan sudah harus diberitahukan apabila terjadi transaksi jual beli saham tersebut. Oleh sebab itu, pada bursa internasional disepakati adanya ex-dividend date yaitu tiga hari sebelum tanggal pencatatan (date of record) setelah tangal pencatatan, saham tersebut tidak lagi memiliki hak atas dividen pada tanggal pembayaran.

5. Date Of Payment (tanggal pembayaran). Dividen dibayarkan kepada pemegang saham setelah memegang dividen, kas di debet dan piutang dieleminasi. Pembayaran dividen akan dikenakan pemotongan pajak penghasilan.

Besar kecilnya dividen yang akan dibayarkan oleh perusahaan tergantung pada kebijakan dividen masing-masing perusahaan, sehingga pertimbangan manajemen sangat diperlukan, salah satu indikator yang menunjukan besarnya nilai dividen yang dibagikan oleh perusahaan kepada investor adalah dividend payout ratio. Dividend Payout Ratio merupakan presentase laba yang dibayarkan dalam bentuk dividen. Pertimbangan besarnya suatu dividend payout ratio diduga berkaitan erat dengan sebuah kinerja manajemen karena kinerja keuangan suatu perusahaan yang cukup baik dan diharapkan untuk menentukan besarnya dividen yang sesuai juga dengan harapan para pemegang saham yang telah 
berinvestasi pada perusahaan tersebut (Rahayuningtyas, 2014).

Dividend payout ratio yang ditentukan perusahaan untuk membayar dividen kepada para pemegang saham setiap tahun dilakukan berdasarkan besar kecilnya laba bersih setelah pajak. Jumlah dividen yang dibayarkan akan mempengaruhi harga saham atau kesejahteraan para pemegang saham (Sirait, 2017:125). Dividend Payout Ratio adalah rasio yang menunjukkan besarnya nilai dividen yang dibagikan oleh perusahaan kepada para investor. Keadaan yang dilematis sering dialami oleh perusahaan dalam melakukan kebijakan dividen itu sendiri, dimana di satu sisi investor menuntut untuk dibagikannya sejumlah dividen setelah kesepakatan dalam Rapat Umum Pemegang Saham (RUPS) agar memperoleh kepercayaan akan kelangsungan prospek perusahaan dimasa mendatang, sedangkan disisi perusahaan menginginkan untuk menahan labanya sebagai langkah dalam melakukan pengembangan investasi guna untuk memperbesar perusahaannya (Yudha dkk, 2017).

\section{Faktor yang mempengaruhi Kebijakan Dividen Firm Size}

Ukuran perusahaan merupakan gambaran banyak sedikitnya perusahaan yang dapat dilihat dalam nilai total aktiva perusahaan. Menurut signaling theory. Firm size yang besar memberikan sinyal positif bagi investor maupun kreditor. Perusahaan yang besar dianggap mampu menaikkan nilai perusahaan, karena pihak manajemen lebih leluasa dalam menggunakan asset yang dimiliki perusahaan untuk meningkatkan produktivitas sehingga akan menaikkan nilai perusahaan. Firm size yang besar juga mampu menggambarkan bila perusahaan memiliki kontrak paling tinggi agar lanjut membetulkan kerjanya, supaya pasar akan siap membiayai lebih tinggi agar memperoleh sahamnya (Hendry dan Fachrurozie, 2015). Menurut (Madyoningrum, 2019) Ukuran perusahaan merupakan salah satu variabel yang banyak digunakan untuk menjelaskan mengenai variasi pengungkapan dalam laporan tahunan perusahaan. Terdapat beberapa penjelasan mengenai pengaruh ukuran perusahaan terhadap kualitas ungkapan. Ukuran perusahaan menggambarkan besar kecilnya suatu perusahaan yang ditunjukkan oleh total asset, jumlah penjualan, rata-rata tingkat penjualan dan rata-rata total asset.

Ukuran perusahaan adalah rata-rata total penjualan bersih untuk tahun yang bersangkutan sampai beberapa tahun. Dalam hal ini penjualan lebih besar daripada biaya variabel dan biaya tetap, maka akan diperoleh jumlah pendapatan sebelum pajak. Sebaliknya jika penjualan lebih kecil daripada biaya variabel dan biaya tetap maka perusahaan akan menderita kerugian (Brigham dan Houston 2001). Keadaan yang dikehendaki oleh perusahaan adalah perolehan laba bersih sesudah pajak karena bersifat menambah modal sendiri. Laba operasi ini dapat diperoleh jika jumlah penjualan lebih besar daripada jumlah biaya variabel dan biaya tetap. (Yudha, dkk 2017).

Semakin besar ukuran perusahaan, diperkirakan memiliki kemampuan untuk menghasilkan earning yang lebih besar sehingga dapat membayar dividen yang lebih tinggi (Marietta dan Sampurno, 2013). Ukuran perusahaan merupakan karakteristik perusahaan yang menentukan nilai perusahaan dan salah satu hal yang dipertimbangkan perusahaan dalam meningkatkan nilai perusahaan. Ukuran perusahaan adalah suatu skala dimana dapat diklasifikasikan besar kecilnya perusahaan menurut berbagai cara antara lain dengan total aktiva, log size, harga pasar saham, dan lain-lain (Mirawati, 2014).

\section{Current Ratio}

Menurut Munawir (2014:72), current ratio yaitu perbandingan antara jumlah aktiva lancar dengan hutang lancar rasio ini menunjukkan bahwa nilai kekayaan lancar yang segera dapat dijadikan uang ada sekian kalinya hutang jangka pendek. Perusahaan yang semakin besar dan sudah stabil akan memiliki akses yang lebih baik di pasar modal, kemampuan meminjam yang lebih besar, fleksibilitas yang lebih besar akan memperbesar kemampuan membayar dividen (Sunyoto, 2015:168).

Current ratio digunakan untuk menentukan kemampuan perusahaan dalam memenuhi kewajiban jangka pendeknya. Semakin besar current ratio yang dimiliki menunjukan besarnya kemampuan perusahaan dalam memenuhi kebutuhan operasionalnya terutama modal kerja yang sangat penting untuk menjaga kinerja perusahaan yang pada akhirnya mempengaruhi harga saham. Hal ini dapat memberikan keyakinan pada investor untuk memiliki saham perusahan tersebut sehingga dapat 
meningkatkan harga saham.namun ternyata ada kenyataan bahwa harga saham meningkat disaat nilai current ratio menurun (Deitiana, 2013). Current ratio merupakan rasio keuangan yang menunjukan proporsi aktiva lancar terhadap kewajiban lancar. Semakin tinggi rasio, maka perusahaan semakin likuid dan akan semakin mudah memperoleh pendanaan dari kreditor maupun investor untuk meningkatkan laba perusahaan. Hal ini dapat diartikan bahwa ketika perusahaan dalam kondisi likuid maka aktivitas produksi perusahaan akan berjalan lancar sehingga akan menghasilkan laba yang ditargetkan. Semakin besar posisi kas dan likuiditas perusahaan secara keseluruhan, maka akan semakin besar pula kemampuan perusahaan untuk membayar dividen (Sarmo, dkk 2019).

Menurut (Samrotun, 2015) Current ratio merupakan kemampuan perusahaan untuk memenuhi kewajiban jangka pendeknya melalui sejumlah aktiva lancar yang dimiliki oleh perusahaan. Semakin tinggi current ratio menunjukkan kemampuan perusahaan dalam memenuhi kewajiban jangka pendeknya (termasuk di dalamnya membayar dividen yang terhutang). semakin tingginya current ratio juga dapat meningkatkan keyakinan para investor untuk membayar dividen yang diharapkan oleh investor.

Current ratio merupakan salah satu ukuran dari rasio likuiditas yang dihitung dengan membagi asset lancar dengan utang lancar. Semakin besar current ratio menunjukkan semakin tinggi perusahaan dalam memenuhi kewajiban financial jangka pendek tepat pada waktunya (Diantini dan Badjra, 2016).

\section{Return On Asset}

Return on assets dapat menunjukkan kemampuan perusahaan memperoleh keuntungan dari asset atau aktiva yang digunakan. Dividen merupakan sebagian dari laba bersih yang diperoleh perusahaan, oleh karenanya dividen akan dibagikan jika perusahaan memperoleh keuntungan. Keuntungan yang layak dibagikan kepada para pemegang saham adalah keuntungan setelah perusahan memenuhi seluruh kewajiban tetapnya yaitu beban bunga dan pajak. Karena dividen diambil dari keuntungan bersih perusahaan maka keuntungan tersebut akan mempengaruhi besarnya dividend payout ratio (Ginting, 2018). Laba bersih mengukur keuntungan setelah dipotong beban bunga, praktik ini membuat profitabilitas yang jelas dari perusahaan sebagai fungsi modalnya. Menurut (Munawir, 2014:89) besarnya return on asset dipengaruhi oleh dua faktor, antara lain :

1. Turnover dari operating asset yaitu tingkat perputaran aktiva yang digunakan untuk kegiatan operasi.

Operating asset ini selisih antara penjualan dengan total aktiva perusahaan tersebut.

2. Profit Margin yaitu besarnya keuntungan operasi yang dinyatakan dalam presentasi dan jumlah penjualan bersih. Profit margin ini mengukur tingkat keuntungan yang dapat dicapai oleh perusahaan dihubungkan dengan penjualannya.

ROA menunjukkan kemampuan modal yang diinvestasikan dalam total aktiva untuk menghasilkan laba perusahaan. Return On Asset adalah salah satu bentuk rasio profitabilitas yang dimaksudkan untuk mengukur kemampuan perusahaan atas keseluruhan dana yang ditanamkan dalam aktivitas operasi perusahaan dengan tujuan menghasilkan laba dengan memanfaatkan aktiva yang dimilikinya (Ardimas, Wahyu, 2014).

Menurut (Hanif dan Bustamam, 2017) Perusahaan yang mempunyai profitabilitas tinggi akan menarik minat investor untuk menanamkan modalnya dengan harapan akan mendapatkan keuntungan yang tinggi pula. Semakin besar Return on asset menunjukkan kinerja perusahaan yang semakin baik, karena tingkat pengembalian investasi (return) semakin besar.

\section{Hipotesis Penelitian}

Berdasarkan latar belakang yang telah diuraikan, serta rumusan masalah dan tujuan penelitian yang telah di uraikan dalam pendahuluan, maka berikut adalah hipotesis yang dapat di ambil dalam penelitian ini :

\section{Pengaruh Firm Size (Ukuran Perusahaan) terhadap Dividend Payout Ratio}

Ukuran perusahaan adalah faktor penting untuk mempengaruhi keputusan membayar dividen. Perusahaan yang memiliki ukuran besar akan cenderung memiliki kemudahan dalam memasuki pasar modal. Hal ini mengurangi ketergantungan dana yang dihasilkan dari dalam perusahaan dan 
memungkinkan pembayaran dividen dengan tingkat yang lebih tinggi (Maura, dkk 2019).

Oktaviani dan Basana (2015) mengungkapkan bahwa ukuran perusahaan berpengaruh tidak signifikan terhadap kebijakan dividen. semakin besar ukuran suatu perusahaan bukan berarti semakin besar pula dividen yang dibagikan sedangkan, penelitian yang dilakukan oleh noviyati dan kamaliah (2015) mengungkapkan bahwa ukuran perusahaan berpengaruh terhadap dividend payout ratio, karena besarnya perusahaan berperan dalam besarnya rasio pembayaran dividen. dengan demikian dapat diambil hipotesis sebagai berikut:

\section{$\mathrm{H}_{1}$ : Firm size berpengaruh secara signifikan terhadap Dividend Payout Ratio}

\section{Pengaruh Current Ratio terhadap Dividend Payout Ratio}

Current ratio merupakan rasio keuangan yang menunjukan proporsi aktiva lancar terhadap kewajiban lancar. Semakin tinggi rasio, maka perusahaan semakin likuid dan akan semakin mudah memperoleh pendanaan dari kreditor maupun investor untuk meningkatkan laba perusahaan. Hal ini dapat diartikan bahwa ketika perusahaan dalam kondisi likuid maka aktivitas produksi perusahaan akan berjalan lancar sehingga akan menghasilkan laba yang ditargetkan. Semakin besar posisi kas dan likuiditas perusahaan secara keseluruhan, maka akan semakin besar pula kemampuan perusahaan untuk membayar dividen (Sarmo, dkk 2019).

Hasil penelitian oleh Diantini dan Badjra (2016) menunjukan hasil Current Ratio berpengaruh positif dan signifikan terhadap kebijakan dividen. Sebaliknya Astiti, dkk (2017) dan Hayati \& Norbaiti (2016) menunjukan bahwa Current Ratio berpengaruh negatif dan signifikan terhadap Dividend Payout Ratio. Dengan demikian dapat diambil hipotesis :

\section{$\mathrm{H}_{2}$ : Current Ratio berpengaruh negatif dan signifikan terhadap Dividend Payout Ratio}

\section{Pengaruh Return On Asset terhadap Dividend Payout Ratio}

Return On Assets menunjukkan kemampuan modal yang diinvestasikan dalam total aktiva untuk menghasilkan laba perusahaan. Semakin tinggi Return On Assets maka kemungkinan pembagian dividen juga semakin banyak (Hanafi, 2013). Perusahaan besar dengan total asset yang tinggi dan keuntungan yang cenderung stabil dapat dengan mudah masuk ke pasar modal atau memperoleh bentuk dana lain dari luar untuk pembiayaannnya. Perusahaan yang masuk kriteria seperti ini akan mempunyai tingkat dividen yang lebih tinggi dengan perusahaan kecil atau yang masih baru dengan laba yang masih berfluktuasi. Perusahaan yang besar dan memiliki profitabilitas yang tinggi akan dengan mudah masuk ke pasar modal atau memperoleh dana-dana yang diperlukan untuk perluasan usahanya dibandingkan dengan perusahaan yang masih baru dan kecil (Sundjaja dan Barlian, 2013).

Hasil penelitian yang dilakukan oleh (Welas, 2017) menunjukan bahwa return on asset tidak berpengaruh terhadap dividend payout ratio. Sedangkan hasil penelitian (Wahyuni dan Hafiz, 2018) return on asset berpengaruh signifikan terhadap dividend payout ratio. Dengan demikian dapat ditarik kesimpulan bahwa:

\section{$\mathrm{H}_{3}$ : Return On Asset berpengaruh positif signifikan terhadap Dividend Payout Ratio}

\section{Pengaruh Firm Size, Current Ratio, dan Return On Asset terhadap Dividend Payout Ratio}

Firm size, Current Ratio, dan Return On Asset mempengaruhi Dividend Payout Ratio. Semakin tinggi Firm Size, Current Ratio, dan Return On Asset maka semakin baik perkembangan atau keberlangsungan hidup perusahaan maupun para pemegang saham karena pembagian dividen yang tinggi. Penelitian terdahulu yang dilakukan oleh (Ibrahim, 2019) dan (Wahyuni dan Hafiz, 2018) berpendapat bahwa Firm size, Current Ratio, dan Return On Asset secara bersama-sama berpengaruh positif dan signifikan terhadap dividend payout ratio. Berdasarkan keterkaitan variabel Firm Size, Current Ratio, dan Return On Asset terhadap Dividend Payout Ratio, maka dapat ditarik kesimpulan bahwa :

$\mathrm{H}_{4}$ : Firm Size, Current Ratio, dan Return On Asset berpengaruh signifikan terhadap Dividend Payout Ratio.

Berdasarkan kajian teori dan hipotesis maka konsep penelitian dapat digambarkan sebagai berikut: 


\section{Gambar 1 \\ Konsep Penelitian}

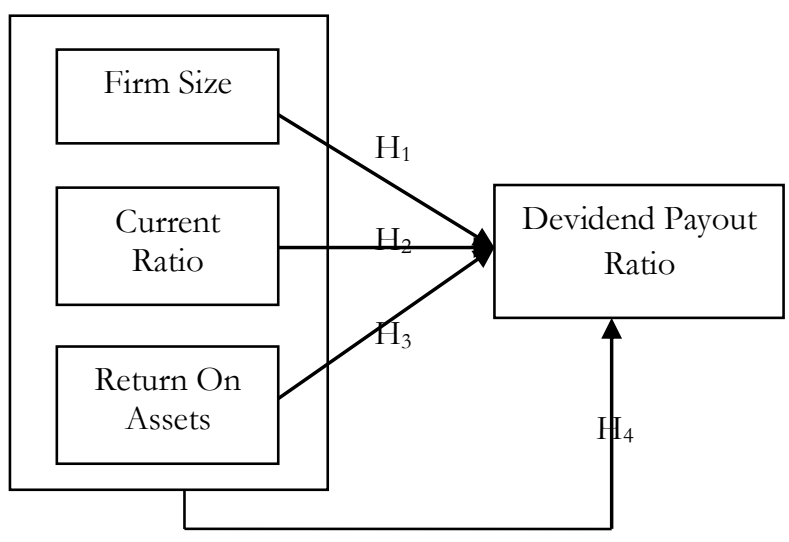

Sumber: Data diolah, 2019

\section{METODE PENELITIAN}

Jenis penelitian yang dilakukan adalah penelitian dengan pendekatan kuantitatif. Menurut Kurniawan (2019) penelitian kuantitatif adalah metode yang lebih menekankan pada aspek pengukuran secara obyektif. Dengan menjabarkan beberapa komponen dan setiap variabel yang di tentukan di ukur dengan memberikan simbol-simbol angka.

Penelitian ini merupakan jenis penelitian kasual komparatif. Penelitian kasual komparatif adalah penelitian yang memiliki tujuan untuk menyelidiki adanya kemungkinan sebab akibat berdasarkan pengamatan terhadap fenomena yang diteliti. Penelitian ini meneliti tentang pengaruh Firm Size, Current Asset, dan Return on Asset terhadap Dividend Payout Ratio pada perusahaan Property, Real estate, dan Konstruksi bangunan yang terdaftar di Bursa Efek Indonesia tahun 2016-2018.

Penelitian ini dilakukan dengan mengambil data di Bursa Efek Indonesia (BEI) melalui situs web www.idx.co.id. Sumber data penelitian ini adalah data sekunder yang diperoleh secara historis dari laporan keuangan dan laporan tahunan yang disajikan perusahaan Property, Real Estate, dan Konstruksi Bangunan yang terdaftar di Bursa Efek Indonesia (BEI) tahun 2016-2018.

\section{Populasi, Sampel dan Teknik Pengambilan Sampel}

Populasi adalah keseluruhan dari objek penelitian yang dapat berupa manusia, hewan, tumbuhtumbuhan, udara, gejala, nilai, peristiwa, sikap hidup, dan sebagainya, sehingga objek-objek ini dapat menjadi sumber penelitian (Bugin, 2011). Jadi populasi bukan hanya orang, tetapi juga obyek dan benda- benda alam yang lain. Populasi bukan hanya sekedar jumlah yang ada pada objek atau subjek yang dipelajari, tetapi meliputi seluruh karaekteristik atau sifat yang dimiliki oleh subjek atau objek itu. Populasi yang digunakan dalam penelitian ini adalah semua perusahaan Property, Real estate sebanyak 48 emiten, Konstruksi Bangunan sebanyak 19 emiten yang terdaftar di Bursa Efek Indonesia (BEI) sebanyak total keseluruhan 67 emiten.

Sampel merupakan suatu bagian dari keseluruhan serta karakteristik yang dimiliki oleh sebuah populasi (Sugiyono, 2008). Apabila populasi itu besar, sehingga peneliti tentunya tidak memungkinkan untuk mempelajari keseluruhan yang ada pada populasi tersebut, maka peneliti menggunakan teknik pengambilan sampel. Penentuan sampel dalam penelitian ini menggunakan teknik purposive sampling.

Teknik sampling merupakan teknik pengambilan sampel atau sebagian elemen populasi untuk memahami karakteristik dari keseluruhan populasi. Peneliti menggunakan metode pengambilan sampel yaitu purpose sampling. Menurut Hendry (2010), bahwa metode pengambilan sampel non probabilitas termasuk di dalamnya metode purpose sampling yaitu teknik penentuan sampel dengan pertimbangan khusus sehingga layak dijadikan sampel agar memudahkan penelitian dalam menarik kesimpulan. Sampel yang digunakan dalam penelitian ini adalah perusahaan-perusahaan yang bergerak di bidang Property, Real estate, dan Konstruksi Bangunan. Adapun kriteria-kriteria perusahaan sampel yang telah ditentukan peneliti adalah : 
Tabel 1

Kriteria Sampel

\begin{tabular}{llc}
\hline No & \multicolumn{1}{c}{ Kriteria Sampel } & $\begin{array}{c}\text { Jumlah } \\
\text { Perusahaan }\end{array}$ \\
\hline 1 & $\begin{array}{l}\text { Perusahaan Property, Real estate, dan Konstruksi bangunan yang terdaftar } \\
\text { di BEI tahun 2016-2018 }\end{array}$ & 67 \\
2 & $\begin{array}{l}\text { Perusahaan Property, Real estate, dan Konstruksi bangunan yang tidak } \\
\text { lengkap dalam melaporkan keuangan selama tahun 2016-2018 }\end{array}$ & $(15)$ \\
3 & $\begin{array}{l}\text { Perusahaan Property, Real estate, dan Konstruksi bangunan yang tidak } \\
\text { memperoleh laba (mengalami kerugian) selama tahun 2016-2018 }\end{array}$ & $(7)$ \\
4 & $\begin{array}{l}\text { Perusahaan Property, Real estate, dan Konstruksi bangunan yang tidak } \\
\text { konsisten dalam membagikan dividen selama tahun 2016-2018 }\end{array}$ & \multicolumn{2}{c}{ Total Sampel } \\
\hline
\end{tabular}

Berdasarkan kriteria diatas, maka perusahaan Property, Real estate, dan Konstruksi bangunan yang masuk dalam kriteria sebanyak 29 perusahaan. Dengan tiga kali publikasi laporan keuangan dari tahun 2016-2018, sehingga jumlah data yang digunakan adalah sebanyak 87 data penelitian.

\section{Definisi Operasional Variabel}

Pengukuran variabel dependen dan independen dijelaskan pada tabel berikut:

\section{Tabel 2}

Definisi Operasional Variabel

\begin{tabular}{lll}
\multicolumn{1}{c}{ Variabel } & \multicolumn{1}{c}{ Pengukuran } & \multicolumn{1}{c}{ Sumber } \\
\hline $\begin{array}{l}\text { Dividend Payout Ratio } \\
\text { (DPR) }\end{array}$ & $\begin{array}{l}\text { DPR = Pembayaran Dividen / Laba } \\
\text { Firm Size (FS) }\end{array}$ & Sudana (2015) \\
& FS = Ln Total Asset & $\begin{array}{l}\text { Samrotun 2015, Oktaviani dan } \\
\text { Basana 2015 }\end{array}$ \\
Current Ratio (CR) & CR=Asset Lancar/Utang Lancar & $\begin{array}{l}\text { Samrotun 2015, } \\
\text { Deitiana 2013 } \\
\text { Return On Asset (ROA) }\end{array}$ \\
& ROA= EAT/Total Asset & Samrotun 2015, Setiawan, dkk \\
& & 2018. \\
\hline
\end{tabular}

Sumber: Data diolah, 2019

\section{HASIL DAN PEMBAHASAN}

\section{Hasil Statistik Deskriptif}

Statistik deskriptif digunakan untuk memberikan gambaran atau deskriptif suatu data yang dilihat dari rata-rata (mean), nilai minimum, nilai maksimum, dan standar deviasi dari masing-masing variabel meliputi Firm Size, Current Ratio, dan Return On Asset terhadap Dividend Payout Ratio, serta jumlah 87 (N) data yang digunakan dalam penelitian ini. Tabel hasil analisis deskriptif dalam penelitian ini adalah sebagai berikut :

Tabel 3

Hasil Analisis Statistik Deskriptif

\begin{tabular}{lrrrrr}
\hline & N & \multicolumn{1}{c}{ Minimum } & Maximum & \multicolumn{1}{c}{ Mean } & Std Deviation \\
\hline FS & 87 & 13,56 & 32,45 & 25,8772 & 5,00104 \\
CR & 87 &, 79 & 7,76 & 2,2995 & 1,31474 \\
ROA & 87 &, 00 &, 36 &, 0580 &, 05230 \\
DPR & 87 &, 00 & 3,97 &, 3704 &, 57708 \\
Valid N (listwise) & 87 & & & & \\
\hline
\end{tabular}

Sumber : Data diolah peneliti, 2019

Berdasarkan Uji SPSS yang telah dilakukan, statistik deskrptif menunjukan gambaran secara umum variabel dependen dan independen. Berdasarkan tabel diatas dapat dijelaskan sebagai berikut : 


\section{Firm Size (Ukuran Perusahaan)}

Tabel 4.3 menunjukkan hasil pengujian statistik deskriptif dari jumlah penelitian $(\mathrm{N})$ adalah sebanyak 87 perusahaan. Firm size menunjukan hasil statistik deskriptif dengan nilai minimum sebesar 13,56, nilai maximum 32,45 dengan rata-rata 25,8772 pada standar deviasi 5,00104. Perusahaan Property, Real Estate, dan Konstruksi bangunan dengan Firm size terendah terjadi pada PT. Fortune Mate Indonesia Tbk pada tahun 2016 sebesar 13,56 sedangkan perusahaan dengan Firm size tertinggi terjadi pada PT. Waskita Karya (Persero) Tbk pada tahun 2018 sebesar 32,45.

\section{Current Ratio (Rasio Lancar)}

Hasil pengujian statistik deskriptif pada tabel menunjukan bahwa variabel Current ratio dengan nilai minimum sebesar 0,79, nilai maximum sebesar 7,76 dengan rata-rata sebesar 2,2995 pada standar deviasi 1,31474. Perusahaan yang memiliki nilai terendah adalah PT. Dadanayasa Arthatama Tbk pada tahun 2016 sebesar 0,79 dan perusahaan dengan nilai current ratio tertinggi adalah PT. Bekasi Fajar Industrial Estate Tbk pada tahun 2018 sebesar 7,76.

\section{Return On Asset (ROA)}

Hasil pengujian statistik deskriptif pada tabel menunjukan bahwa variabel Return On asset dengan nilai minimum 0,00, nilai maximum 0,36 dengan rata- rata 0,0580 pada standar deviasi 0,05230. Perusahaan yang memiliki nilai return on asset terendah terjadi pada PT. Lippo Karawaci Tbk pada tahun 2017 sebesar 0,00 sedangkan perusahaan dengan nilai tertinggi terjadi pada PT. Fortune Mate Indonesia Tbk pada tahun 2016 sebesar 0,36.

\section{Dividend Payout Ratio (DPR)}

Pada tabel diatas menunjukan bahwa varial dependen Dividend payout ratio dengan nilai minimum sebesar 0,00 nilai maximum 3,97 dengan rata-rata 0,3704 pada standar deviasi 0,57708. Perusahaan yang memiliki rasio pembayaran dividen terendah adalah PT. Bekasi Fajar Industrial Estate Tbk pada tahun 2016 sebesar 0,00. Sedangkan perusahaan dengan rasio pembayaran dividen tertinggi terjadi pada PT. Modernland Realty Tbk sebesar 3,97 pada tahun 2018.

\section{Analisis Regresi Linear Berganda}

Tabel 4

Hasil Uji Regresi

\begin{tabular}{|c|c|c|c|c|c|}
\hline \multirow[t]{2}{*}{ Model } & \multicolumn{2}{|c|}{ Unstandardized Coefficients } & \multirow{2}{*}{$\begin{array}{c}\begin{array}{c}\text { Standardized } \\
\text { Coefficients }\end{array} \\
\text { Beta }\end{array}$} & \multirow[t]{2}{*}{$\mathrm{t}$} & \multirow[t]{2}{*}{ Sig } \\
\hline & B & Std.Error & & & \\
\hline (Constant) & ,301 & ,070 & & 4,321 & ,000 \\
\hline FS &,- 002 & ,002 &,- 114 &,- 978 & ,332 \\
\hline CR &,- 037 & 010 &,- 437 & $-3,696$ &, 000 \\
\hline ROA &, 045 & ,327 &, 016 & ,137 & 892 \\
\hline
\end{tabular}

a. Dependent Variable: DPR

Sumber : Data diolah peneliti, 2019

Berdasarkan hasil analisis dengan software SPSS 22 pada tabel 4.11 dapat dirumuskan persamaan regresi linear berganda sebagai berikut :

$$
\mathrm{DPR}=0,301-0,002 \mathrm{FS}-0,037 \mathrm{CR}+0,045 \mathrm{ROA}+e
$$

Hasil uji analisis regresi menunjukkan bahwa jika nilai DPR nol (0), maka nilai ROA meningkat sebesar 0,045. Namun ketika DPR memiliki nilai nol (0), maka nilai FS menurun sebesar 0,002 dan nilai CR menurun sebesar 0,037 . 


\begin{tabular}{|c|c|c|c|c|c|c|}
\hline \multicolumn{7}{|c|}{$\begin{array}{c}\text { Tabel } 5 \\
\text { Uji Simultan (Uji f) }\end{array}$} \\
\hline Model & $\begin{array}{l}\text { Sum of } \\
\text { Squares }\end{array}$ & & $\mathrm{df}$ & Mean Square & F & Sig. \\
\hline Regression & & 119 & 3 & 040 & 4,972 &, $004^{\mathrm{b}}$ \\
\hline Residual & & ,470 & 59 & ,008 & & \\
\hline Total & & ,589 & 62 & & & \\
\hline
\end{tabular}

a. Dependent variable: DPR

b. Predictors (Constant): FS, CR,ROA

Hasil perhitungan pada tabel diatas diperoleh nilai $\mathrm{F}$ sebesar 4,972 dan nilai signifikansi sebesar 0,004. Karena nilai signifikansi lebih kecil dari tingkat kepercayaan yang digunakan 5\%, berarti terdapat pengaruh yang signifikan, sehingga variabel independen cukup kuat untuk memprediksi variabel dependen. Hal ini menunjukan ada pengaruh secara simultan antara Firm Siz̨e, Current Ratio, dan Return on Asset terhadap Dividend Payout Ratio, sehingga model dianggap layak sebagai alat prediksi.

\section{Uji Parsial (Uji t)}

Uji parsial (uji t) untuk mengetahui apakah secara individu (parsial) ketiga variabel independen berpengaruh terhadap variabel dependen. Selain itu untuk menguji ketepatan model regresi. Pengujian hasil regresi dilakukan menggunakan uji t pada derajat keyakinan $95 \%$ atau $a=5 \%$.

Berdasarkan output SPSS pada tabel 4 diatas menunjukkan bahwa dari ketiga variabel independen yang dimasukkan ke dalam model regresi, terdapat satu variabel yang berpengaruh signifikan terhadap Dividend payout ratio yaitu Current ratio. Hal ini dapat dilihat dari nilai signifikansi untuk Current Ratio sebesar 0,000 dimana nilainya lebih kecil dari 0,05. Secara statistika, kenaikan Current ratio satu satuan menyebabkan angka Dividend payout ratio turun $-0,037$ satuan. Variabel lainnya yaitu Firm size dengan nilai signifikansi sebesar 0,332 dan Return on asset sebesar 0,892 memiliki nilai signifikansi lebih besar dari 0,05 yang berarti bahwa variabel firm size dan return on asset tidak memiliki pengaruh signifikan terhadap dividend payout ratio.

\section{Firm Size}

Hipotesis 1 bertujuan untuk menguji pengaruh Firm size terhadap Dividend payout ratio. Hasil dari uji t pada tabel 4.12 menunjukan nilai t hitung sebesar $-0,978$ dengan nilai signifikansi 0,332 . Karena nilai t hitung lebih kecil dari t-tabel 2,001 dan nilai signifikansi lebih besar dari 0,05, dengan demikian dapat disimpulkan bahwa hipotesis 1 ditolak, ini berarti variabel Firm size tidak berpengaruh terhadap Dividend payout ratio. Hasil ini didukung oleh penelitian yang dilakukan Simanjuntak (2016) dan Oktaviani \& Basana (2015) yang mengungkapkan bahwa Firm Size atau ukuran perusahaan berpengaruh tidak signifikan terhadap Dividend Payout Ratio.

\section{Current Ratio}

Hipotesis 2 bertujuan untuk menguji pengaruh Current ratio terhadap Dividend payout ratio. Hasil uji t Current ratio terhadap Dividend payout ratio menunjukan nilai t hitung sebesar -3,696 dengan nilai signifikansi sebesar 0,000. Karena nilai t hitung lebih besar dari t-tabel 2,001 dan nilai signifikansi lebih kecil dari 0,05, dengan demikian dapat disimpulkan bahwa hipotesis 2 diterima, artinya secara statistik dapat ditunjukan bahwa current ratio berpengaruh negatif dan signifikan terhadap dividend payout ratio. Hasil ini didukung oleh penelitian yang dilakukan Yasa, dkk (2016) yang mengungkapkan bahwa Current Ratio berpengaruh negatif dan signifikan terhadap Dividend Payout Ratio.

\section{Return On Asset}

Hipotesis 3 bertujuan untuk menguji pengaruh signifikan Return on Asset terhadap Dividend Payout Ratio. Berdasarkan hasil pengujian pada tabel 4.12 menunjukan bahwa current ratio tidak berpengaruh signifikan terhadap dividend payout ratio. Karena nilai signifikansi lebih besar dari 0,05 yaitu sebesar 0,892. Dengan demikian dapat disimpulkan bahwa hipotesis 3 ditolak, artinya secara 
statistika Return on Asset tidak berpengaruh signifikan terhadap Dividend payout ratio karena nilai signifikansi lebih besar dari 0,05. Hasil ini didukung oleh penelitian yang dilakukan Putri dan Widodo (2016), Welas (2017) dan Steven (2017) yang mengungkapkan bahwa Return on asset tidak berpengaruh signifikan terhadap Dividend Payout Ratio.

\section{Uji Koefisien Determinasi}

Uji koefisien Determinasi dengan melihat nilai Adjusted R Square :

\section{Tabel 6}

Hasil Uji Koefisien Determinasi Model Summary ${ }^{\mathrm{b}}$

\begin{tabular}{lllll}
\hline Model & $\mathrm{R}$ & R Square & Adjusted R Square & $\begin{array}{c}\text { Std. Error of } \\
\text { the Estimate }\end{array}$ \\
\hline 1 &, $449^{\mathrm{a}}$ &, 202 &, 161 &, 08927 \\
\hline
\end{tabular}

a. Predictors: (Constant), FIRM SIZE, CURRENT RATIO, RETURN ON ASSET

b. Dependent Variable: DIVIDEND PAYOUT RATIO

Sumber : Data diolah peneliti, 2019

Hasil tampilan output SPSS pada tabel 4.14 menunjukan nilai Adjusted R Square sebesar 0,161, hal ini berarti $16,1 \%$ variasi variabel dependen yaitu Dividend Payout Ratio dapat dijelaskan oleh variasi dari ketiga variabel independen Firm Size, Current Ratio, dan Return On Asset. Sedangkan sisanya (100\% $16,1 \%=83,9 \%$ ) dijelaskan oleh sebab-sebab lain diluar model.

\section{KESIMPULAN DAN SARAN \\ Kesimpulan}

Penelitian ini bertujuan untuk mengetahui pengaruh Firm Size, Current Ratio, dan Return On Asset terhadap Dividend Payout Ratio pada perusahaan jasa sektor Property, Real Estate, Konstruksi dan Bangunan yang terdaftar di Bursa Efek Indonesia periode 2016-2018. Berdasarkan hasil analisis regresi linear berganda, maka dapat disimpulkan sebagai berikut :

1. Firm Size tidak berpengaruh dan tidak signifikan terhadap Dividend Payout Ratio. Hasil ini dibuktikan dengan nilai signifikansi sebesar 0,332 lebih besar dari signifikansi yang disyaratkan yaitu sebesar 0,05, oleh karena itu hipotesis pertama menyatakan Firm Siz̨e berpengaruh signifikan terhadap Dividend Payout Ratio ditolak.

2. Current Ratio berpengaruh negatif dan signifikan terhadap Dividend Payout Ratio. Hasil ini dibuktikan dengan nilai signifikansi sebesar 0,000 lebih kecil dari 0,05, oleh karena itu hipotesis kedua diterima. Hal ini menunjukan bahwa setiap kenaikkan nilai current ratio pada umumnya akan menurunkan kemampuan perusahaan untuk membayarkan dividen kepada pemegang saham.

3. Return On Asset tidak berpengaruh signifikan terhadap Dividend Payout Ratio karena nilai signifikansi lebih besar dari 0,05 yaitu sebesar 0,892. Oleh karena itu hipotesis ketiga menyatakan Return On Asset berpengaruh positif signifikan terhadap Dividend Payout Ratio ditolak.

4. Variabel Firm Size, Current Ratio, dan Return On Asset secara simultan berpengaruh signifikan terhadap Dividend Payout Ratio dengan nilai signifikansi 0,004 lebih kecil dari nilai tingkat kepercayaan $5 \%$ atau 0,05 .

\section{Keterbatasan Penelitian}

Penelitian ini memiliki keterbatasan diantaranya sebagai berikut :

1. Keterbatasan waktu, penelitian ini hanya menggunakan periode tiga tahun yaitu dari tahun 20162018.

2. Data yang digunakan dalam penelitian ini adalah data perusahaan jasa sektor property, real estate, dan konstruksi bangunan yang terdaftar di Bursa Efek Indonesia dan sampel yang digunakan hanya 29 perusahaan yang memenuhi kriteria karena banyak perusahaan yang tidak membagikan dividen 
secara konsisten.

3. Variabel penelitian sangat terbatas, padahal masih banyak faktor yang mempengaruhi kebijakan dividen seperti struktur modal, struktur kepemilikan, arus kas bebas, dan lain-lain.

\section{Saran}

Berdasarkan kesimpulan dan keterbatasan yang dijelaskan sebelumnya, dapat disampaikan beberapa saran antara lain :

1. Bagi Perusahaan, sebelum melakukan kebijakan membagikan dividen harus mengkaji terlebih dahulu faktor-faktor yang mempengaruhi besar kecilnya pembagian dividen sehingga dalam pelaksanaannya nanti akan saling menguntungkan antara pihak perusahaan dan investor.

2. Bagi investor yang akan melakukan investasi dan memiliki preferensi untuk mendapatkan return berupa dividen, disarankan untuk lebih mempertimbangkan mengenai informasi mengenai rasiorasio keuangan karena informasi tersebut diperlukan untuk memprediksi besarnya dividen yang akan dibagikan oleh perusahaan.

3. Bagi penelitian selanjutnya yang akan melakukan penelitian dengan topik yang sama disarankan untuk menambah varialbel independen atau mengganti variabel independen yang tidak signifikan dalam penelitian ini dengan variabel lain yang dapat mempengaruhi Dividend Payout Ratio, sehingga diperoleh daya prediksi yang lebih baik.

\section{DAFTAR PUSTAKA}

Atmoko, Y., Defung, F., dan Tricahyadinata, I. 2017. Pengaruh Return On Asset, Debt to Equity Ratio, dan Firm Size terhadap Dividend Payout Ratio. Vol. 14 No. 2 2017:103-109.

Deitiana, T. 2013. Pengaruh Current Ratio, Return On Equity, dan Total Asset Turnover terhadap Dividend Payout Ratio dan Implikasi pada Harga saham perusahaan LQ45. Jurnal Bisnis dan Akuntansi, Vol.15 No. 1, Juni 2013 Hlm.82-88.

Diantini, O. \& Badjra, I. B. 2016. Pengaruh Earning per Share, Tingkat Pertumbuhan Perusahaan, dan Current Ratio terhadap Kebijakan Dividen. e-jurnal manajemen UNUD, Vol. 5 No. 11, 2016:6795-6824.

Ghozali, I. 2016. Aplikasi Analisis Multivariate dengan Program IBM SPSS 23. Semarang : Badan Penerbit Universitas Diponegoro.

Ginting, S. 2018. Pengaruh Likuiditas, Profitabilitas, dan Laverage terhadap Kebijakan Dividen pada perusahaan LQ45 yang terdaftar di BEI periode 2012-2016. Vol. 8 No. 2, Oktober 2018.

Gumanty, T. A. 2013. Kebijakan Dividen, Teori, Empiris, dan Implikasi. Yogyakarta : UPP STIM YKPN.

Hadila, D. M \& Hapsari, D. W. 2018. Pengaruh Likuiditas, Profitabilitas, dan Laverage terhadap Kebijakan Dividen (Studi kasus pada perusahaan indeks LQ45 non keuangan yang terdaftar di BEI periode 2013-2016. e-proceeding of management, Vol. 5 No. 3, Desember $2018 \mathrm{Hlm} .3473$.

Hanif, M. \& Bustaman. 2017. Pengaruh Debt to Equity Ratio, Return On Asset, Firm Size, dan Earning per Share terhadap Dividend Payout Ratio. Jurnal Ilmiah Mahasiswa Ekonomi Akuntansi, Vol. 2 No. 1 2017, Hlm. 73-81.

Harun, S. 2018. Pengaruh Profitabilitas, Free Cash Flow, Laverage, Likuiditas, dan Size terhadap Dividend Payout Ratio pada perusahaan manufaktur yang terdaftar di BEI. Jurnal Riset Akuntansi, Vol. 5 No. 2 Maret 2018, Hlm.122-137.

Hayati, N. \& Norbaiti. 2016. Pengaruh Cash Position, Return On Asset, Return On Equity, Debt to Equity Ratio, Current Ratio, dan Asset Growth terhadap Dividend Payout Ratio pada perusahaan manufaktur sektor industri. Jurnal Spread, Vol. 6 No. 1 April 2016.

Ibrahim, M. (2019). Pengaruh Debt to Equity Ratio, Return On Asset, dan Curent Ratio terhadap Dividend Payout Ratio pada perusahaan sub sektor farmasi. Jurnal Aplikasi Manajemen dan Inovasi Bisnis, Vol. 1 No. 2 Februari 2019.

Imawati, M. \& Rodoni, A. 2016. Faktor-faktor yang mempengaruhi Dividend Payout Ratio studi empiris pada perusahaan manufaktur yang terdaftar di BEI. Jurnal Ekonomi, Vol. 18 No. 1 Februari 2016. 
Khotimah, C. \& Waryati, S. Y. 2015. Analisis Pengaruh Cash Position, Debt to Equity Ratio, dan Return On Asset terhadap Dividend Payout Ratio pada perusahaan manufaktur yang terdaftar di BEI Periode 2010-2013. Jurnal Bisnis dan Akuntansi, Vol. 6 No. 1.

Laporan Keuangan \& Tabunan. 2019. Diambil kembali dari www.idx.co.id: http: // www.idx.co.id/idberanda/perusahaantercatat/laporankeuangandantah unan.aspx

Madyoningrum, A. W. 2019. Pengaruh Firm Size, Laverage, dan Profitabilitas terhadap Kebijakan Dividen. Jurnal Bisnis dan Manjemen, Vol. 6 No. 12019 Hlm.45-55.

Mardani, M. R. 2018. Pengaruh Return on Asset, Debt to Total Asset, Current Ratio, Growth dan Firm Size terhadap Kebijakan Dividen. Jurnal Inovasi Bisnis dan Manajemen Investasi, Vol. 1 No. 1 Maret 2018.

Maura, A., Reslita, A., Pratama, D. A., dan Sitepu, C. P. Y. 2019. Pengaruh Current Ratio, Net Profit Margin, Firm Size, terhadap Dividend Payout Ratio pada perusahaan sektor Insfrastructure, Utilities, and Transportation. Jurnal Ilmiah Secio Secretum, Vol. 9 No. 1 tabun 2019, Juni:14-26.

Noviyati, S. \& Kamaliah. 2015. Faktor-faktor yang mempengaruhi kebijakan pembayaran dividen kas (studi pada perusahaan manufaktur yang terdaftar di BEI). Jurnal Tepak Manajemen Bisnis, Vol. VII No. Hlm. 295- 311.

Nuraeni. 2013. Analisis Faktor-faktor yang mempengaruhi kebijakan pembagian dividen pada perusahaan food and baverages yang listing di BEI. Jurnal Yudharta, Vol. 4 No. 2

Parera, D. 2016. Pengaruh Net Profit Margin, Return on Asset, dan Debt to Equity Ratio terhadap Dividend Payout Ratio pada perusahaan indeks LQ45 di BEI. Jurnal EMBA, Vol. 4 No. 2 Juni 2016, Hlm. 538-548.

Pepatih, S. Z. 2016. Pengaruh Return on Asset dan Debt to Equity Ratio terhadap Dividend Payout Ratio pada perusahaan manufaktur sektor industri dasar dan kimia yang terdaftar di BEI. Ejurnal Apresiasi Ekonomi, Vol. 4 No. 3 September 2016:205-211.

Pradana, L. W. S. \& Sanjaya, I. P. S. 2017. Dampak Profitabilitas, Aliran Kas Bebas, dan Kesempatan Investasi terhadap pembayaran dividen perusahaan perbankan. Jurnal keuangan dan perbankan, Vol. 21 No. 1 Januari 2017:113-124.

Putri, F. V. \& Widodo, A. 2016. Pengaruh Return on Asset, Debt to Equity Ratio dan Asset Growth terhadap Dividend Payout Ratio perusahaan pertambangan di BEI tahun 2010-2014. Ecodemia, Vol. IV No. 1 April 2016.

Samrotun, Y. C. 2015. Kebijakan Dividen dan faktor-faktor yang mempengaruhinya. Jurnal Paradigma, Vol. 13 No. 1, Februari-Juli 2015.

Sarmo, S \& Effendi, H. A. 2019. Pengaruh Earnings After Tax, Current Ratio, Debt to Equity Ratio terhadap Dividend Payout Ratio. Jurnal Ilmiah, Vo. 16 No. 1, Januari 2019:86-98.

Silaban, D. P. \& Purnawati, N. K. 2016. Pengaruh Profitabilitas, Struktur Kepemilikan, Pertumbuhan Perusahaan, dan Efektivitas Usaha terhadap Kebijakan Dividen pada perusahaan manufaktur. E-Jurnal Manajemen Unud, Vol. 5 No. 2, 2016:1251-1281.

Simanjuntak, M. S. 2016. Pengaruh Return On Asset, Growth, Total Asset Turnover, Ownership, Firm Size, dan Debt to Total Asset terhadap Dividend Payout Ratio pada perusahaan yang terdaftar di BEI tahun 2010-2012. Jurnal Lentera Akuntansi, Vol. 2 No. 2 November 2016.

Simbolon, K. \& Sampurno, D. 2017. Analisis Pengaruh Firm Size, Debtto Equity Ratio, Asset Growth, Return on Equity, Earning per Share, Quick Ratio dan Past Dividend terhadap Dividend Payout Ratio (Studi kasus perusahaan manufaktur yang terdaftar di BEItahun 20112015). Diponegoro Journal of Management, Vol. 6 No. 3 tabun 2017, Hlm. 1-3.

Steven, S. 2017. Pengaruh Debt to Asset Ratio, Rasio Kas, Size, Return On Asset, Growth, dan Kepemilikan Institutional terhadap Dividend Payout Ratio perusahaan sektor perbankan. Jurnal Bisnis dan Akuntansi, Vol. 19 No. 1 Juni 2017, Hlm.117-128.

Sunaryo. 2014. Analisis Faktor-faktor yang mempengaruhi Dividend Payout Ratio pada perusahaan sektor industri yang terdaftar di BEI. Binus Business Review, Vol. 5 No. 1 Mei 2014:220-229.

Wahyuni, S. F. \& Hafiz, M. S. 2018. Pengaruh Current Ratio, Debt to Equity Ratio dan Return on Asset terhadap Dividend Payout Ratio pada perusahaan manufaktur di BEI. Jurnal Ekonomi \& Ekonomi Syariah, Vol. 1 No. 2 Juni 2018. 
Welas. 2017. Pengaruh Posisi Kas, Ukuran Perusahaan, Return On Asset, dan Debt to Total Asset terhadap Dividend Payout Ratio (Studi Empirik pada perusahaan LQ45 yang terdaftar di BEI periode 2011-2015). Jurnal Akuntansi dan Keuangan, Vol. 6 No. 1 april 2017.

Wicaksono, S. \& Nasir, M. 2014. Faktor-faktor yang mempengaruhi Kebijakan Dividen pada perusahaan manufaktur yang terdaftar di BEI. Vol. 3 No. 4 tahun 2014.

Yasa, K. D. M \& Wirawati, N. G. P. 2016. Pengaruh Net Profit Margin, Current Ratio, dan Debt to Equity Ratio pada Dividend Payout Ratio. E-Jurnal Akuntansi Universitas Udayana 